\title{
Maxillofacial injuries resulting from the practice of sports activities: a cross-sectional
}

\section{study}

\author{
Lesões maxilofaciais decorrentes da prática de atividades esportivas: um estudo transversal
}

Lesiones maxilofaciales resultantes de la práctica de actividades deportivas: un estudio transversal

Rodrigo Caillaux Pereira

ORCID: https://orcid.org/0000-0002-7346-8777 Universidade Federal de Minas Gerais, Brasil E-mail: rodrigocaillaux@ig.com.br

Carlos José de Paula Silva

ORCID: https://orcid.org/0000-0001-5188-4625 Universidade Federal de Minas Gerais, Brasil E-mail: case.odo@gmail.com

Janice Simpson de Paula

ORCID: https://orcid.org/0000-0002-5396-0959

Universidade Federal de Minas Gerais, Brasil E-mail: janicesimpsondp@gmail.com

Raquel Gonçalves Vieira-Andrade ORCID: https://orcid.org/0000-0003-0284-7216

Universidade Federal de Minas Gerais, Brasil E-mail: raquelvieira.andrade@gmail.com

Guilherme Carvalho Silva

ORCID: https://orcid.org/0000-0001-5123-1333

Universidade Federal de Minas Gerais, Brasil E-mail: gccs@ufmg.br

Lucas Thomazotti Berard

ORCID: https://orcid.org/0000-0003-1250-4970

Universidade de São Paulo, Brasil E-mail: lucas.berard@usp.br

Neide Pena Coto

ORCID: https://orcid.org/0000-0002-3235-0684

Universidade de São Paulo, Brasil E-mail: npcoto@usp.br

Miriam Pimenta Parreira do Vale

ORCID: https://orcid.org/0000-0002-8781-778X

Universidade Federal de Minas Gerais, Brasil

E-mail:miriamodonto@gmail.com

\begin{abstract}
The occurrence of maxillofacial injury increases as a result of a great demand for the practice of sports activities worldwide. Maxillofacial injuries can cause a series of losses for individuals who practice physical activities, resulting in emotional and functional consequences, decreased athletic performance, and financial losses. This study aimed to carry out an analysis of the data obtained from medical records of patients with maxillofacial injury due to sports practices. Medical records of patients seen at the Hospital between January 2008 and May 2019 were evaluated, whose attendance occurred as a result of sports activities. Independent variables were related to the type of maxillofacial injury that occurred. The records of 739 patients were analyzed. The occurrence of maxillofacial injury was more prevalent in adolescents and young adult males, as a result of playing soccer. The most prevalent type of injury was soft tissue, with the middle third of the face and the central region being the most frequently affected. Maxillofacial injury was more prevalent in adolescents and young male adults, due to the practice of soccer, typically affecting soft tissues, the middle third of the face, and the central region. The treatment performed was, mostly, conservative.
\end{abstract}

Keywords: Athletic performance; Maxillofacial injuries; Sports.

\section{Resumo}

A ocorrência de lesões maxilofaciais aumenta em decorrência de uma grande demanda pela prática de atividades esportivas em todo o mundo. As lesões maxilofaciais podem causar uma série de prejuízos para os praticantes de atividades físicas, resultando em consequências emocionais e funcionais, diminuição do desempenho esportivo e 
prejuízos financeiros. Este estudo teve como objetivo realizar uma análise dos dados obtidos em prontuários de pacientes com lesão maxilofacial decorrente de práticas esportivas. Foram avaliados prontuários de pacientes atendidos no Hospital entre janeiro de 2008 e maio de 2019, cujo atendimento ocorreu em por causa de atividades esportivas. As variáveis independentes foram relacionadas ao tipo de lesão maxilofacial ocorrida. Os prontuários de 739 pacientes foram analisados. A ocorrência de lesão maxilofacial foi mais prevalente em adolescentes e adultos jovens do sexo masculino, por conta da prática do futebol. O tipo de lesão mais prevalente foi em tecidos moles, sendo o terço médio da face e a região central os mais acometidos. A lesão maxilofacial foi mais prevalente em adolescentes e adultos jovens do sexo masculino, devido à prática do futebol, acometendo tipicamente tecidos moles, terço médio da face e região central. O tratamento realizado foi, em sua maioria, conservador.

Palavras-chave: Atividades esportivas; Desempenho esportivo; Lesões maxilofaciais.

\section{Resumen}

La ocurrencia de traumatismos maxilofaciales aumenta debido a una gran demanda para la práctica de actividades deportivas en todo el mundo. Las lesiones maxilofaciales pueden causar una serie de pérdidas para quienes practican actividades físicas, resultando en consecuencias emocionales y funcionales, disminución del rendimiento atlético y pérdidas económicas. Este estudio tuvo como objetivo realizar un análisis de los datos obtenidos de las historias clínicas de pacientes con lesión maxilofacial resultante de los deportes. Se evaluaron las historias clínicas de los pacientes atendidos en el Hospital entre enero de 2008 y mayo de 2019, cuya atención se produjo por motivo de actividades deportivas. Las variables independientes se relacionaron con el tipo de lesión maxilofacial ocurrida. Se analizaron las historias clínicas de 739 pacientes. La ocurrencia de lesiones maxilofaciales fue más prevalente en adolescentes varones y adultos jóvenes, debido a la práctica del fútbol. El tipo de lesión más prevalente fue en tejidos blandos, siendo el tercio medio de la cara y la región central los más afectados. La lesión maxilofacial fue más prevalente en varones adolescentes y adultos jóvenes, debido a la práctica del fútbol, afectando típicamente tejidos blandos, tercio medio de la cara y región central. El tratamiento realizado fue mayoritariamente conservador.

Palabras clave: Deportes; Rendimiento atlético; Traumatismos maxilofaciales.

\section{Introduction}

Regular practice of physical activities improves the physical, social, and psychological aspects of practitioners (Puciato et al., 2017; Marker et al., 2018), which has increased the search for physical activity (Cevada et al., 2012). As a consequence, clubs, gyms, and sports centers are full of students who practice a wide variety of sports and are part of diversified physical activity programs, influenced by the local culture for a particular sport or activity (Maillane-Vanegas et al., 2018). In parallel to this process, the number of maxillofacial injuries has increased considerably, which has brought great concern from the international and national scene (Correa et al., 2010; Frontera et al., 2011).

Maxillofacial injury can occur in a variety of situations, including sports (Nonoyama et al., 2016; Collins et al., 2016; Tiryaki et al., 2017). Conceptually, maxillofacial injury is defined as a mechanical, thermal, or chemical aggression suffered by the tooth or other structures of the face and skull, which can be characterized by type, intensity, and varied causes (Eroje et al., 2020). In addition, maxillofacial injuries occur from different origins and may occur in isolation or in association with other injuries in different regions of the body, such as cranial, cervical, and limb injuries (Andrade et al., 2010).

The occurrence of maxillofacial injury as a result of sports practice, has been observed in several sports, with a prevalence varying between 20 and 60\% (Farrington et al., 2012; Petrovic et al., 2016; Bruggesser et al., 2020). In addition, this prevalence has been associated with some variables, such as gender (Farrington et al., 2012; Murphy et al., 2015), age (Martinez et al., 2014), and sports activity (Biagi et al., 2010; Ashley et al., 2015), in addition to cultural and social factors that, in the long run, determine a predilection for a particular sport or sporting activity in a region or country (Maillane-Vanegas et al., 2018).

Studies that evaluated maxillofacial injury in athletes showed that its occurrence is of great relevance due to the possibility of injuries affecting their career (Young et al., 2015), bringing with it emotional and functional consequences (Tuna, Ozel, 2014) and high assistance cost associated with these injuries (Welch et al., 2010). In this context, the occurrence of this type of injury in individuals who practice sports activities constitutes an extremely important and relevant health problem in 
today's society and knowledge of this information makes it possible to establish measures to minimize the occurrence of these events and propose actions directed to sports, and the public that have a higher incidence of injuries, as well as training professionals to ensure preventive measures and treatments appropriate to the specificities of maxillofacial injury (de Araújo et al., 2021; Ribeiro et al., 2021; Farrington et al., 2012).

Thus, this study aimed to carry out an analysis of the data obtained from medical records of patients with maxillofacial injury due to sports practices.

\section{Methodology}

The data obtained from medical records of patients with maxillofacial injury due to sports practices, seen at a public hospital reference center for maxillofacial surgery.

This study was approved by the local Human Research and Ethics Committee (CAAE: 61101616.7.0000.5149) and all research participants signed an informed consent form.

The medical records of patients seen at the maxillofacial surgery were included in the study, whose attendance was due to sports activities. Of patients seen between January 2008 and May 2019, 739 medical records were analyzed. Factors associated with the occurrence of maxillofacial injury were evaluated, such as sex, age, sports activity, period of attendance, day, month, and year of occurrence, type of injury, location of the injury, and type of treatment performed. For this analysis, the elderly and an adult individual were excluded for having a variable month of occurrence of maxillofacial injury excluded.

The study was quantitative, transversal, descriptive, and inferential (Pereira et al., 2018). For this, frequency and percentage distribution tables were used to describe the quantitative results and the independent variables were related to the type of maxillofacial injury that occurred through inferential statistics.

Statistical analyses were performed using the Statistical Package for the Social Sciences (SPSS) version 15.0 for Windows. Pearson's chi-square test and Fisher's exact test were used to assess statistical differences between the data. Values of $p<0.05$ were considered statistically significant.

\section{Results}

In total, medical records of 739 patients seen in the period from January 2008 to May 2019 were included in the study. These patients were identified with sociodemographic characteristics (age and sex) (Table 1).

Table 1. Age range and sex of patients included in the study.

\begin{tabular}{cccc}
\hline Variables & Classification & $\mathbf{N}$ & $\mathbf{\%}$ \\
\hline \multirow{5}{*}{ Age Range } & 0 to 9 years (Child) & 57 & 7.7 \\
& 10 to 19 years (Adolescent) & 265 & 35.9 \\
& 20 to 29 years (Young Adult) & 269 & 36.4 \\
& 30 to 59 years (Adult) & 145 & 19.6 \\
& 60 y ears or older (Elderly) & 3 & 0.4 \\
\hline \multirow{2}{*}{ Gender } & Male & 679 & 91.9 \\
& Female & 60 & 8.1 \\
\hline
\end{tabular}

Source: Authors. 
The majority of patients included in the study were characterized as adolescents and young adults $(72.3 \% ; \mathrm{n}=534)$. The elderly were less frequently represented $(0.4 \% ; n=3)$, followed by children $(7.7 \% ; n=57)$. With regard to gender, the largest share of patients was male $(91.9 \% ; \mathrm{n}=679)$.

The consultations performed were categorized in relation to the period (day or night), day (weekdays or weekends), month, and year (Table 2), with the majority taking place at night (64.8\%) and on the weekends (53.6\%). The month with the highest number of visits was October $(10.6 \% ; n=78)$, followed by May $(9.3 \% ; n=69)$, April $(9.2 \% ; n=68)$, and September $(9,1 \% ; n=67) .2008$ was the year with the highest number of visits $(13.8 \% ; n=102)$ in the entire period evaluated.

Table 2. Period, day, month and year of care for patients included in the study.

\begin{tabular}{|c|c|c|c|}
\hline Variables & Classification & $\mathbf{N}$ & $\%$ \\
\hline \multirow{2}{*}{ Period } & Daytime & 260 & 35.2 \\
\hline & Nightly & 479 & 64.8 \\
\hline \multirow{2}{*}{ Day } & Week days & 343 & 46.4 \\
\hline & Weekends & 396 & 53.6 \\
\hline \multirow{12}{*}{ Month } & January & 56 & 7.6 \\
\hline & February & 48 & 6.5 \\
\hline & March & 55 & 7.4 \\
\hline & April & 68 & 9.2 \\
\hline & May & 69 & 9.3 \\
\hline & June & 60 & 8.1 \\
\hline & July & 53 & 7.2 \\
\hline & August & 66 & 8.9 \\
\hline & September & 67 & 9.1 \\
\hline & October & 78 & 10.6 \\
\hline & November & 65 & 8.8 \\
\hline & December & 53 & 7.3 \\
\hline \multirow{12}{*}{ Year } & 2008 & 102 & 13.8 \\
\hline & 2009 & 93 & 12.6 \\
\hline & 2010 & 92 & 12.4 \\
\hline & 2011 & 86 & 11.6 \\
\hline & 2012 & 80 & 10.8 \\
\hline & 2013 & 88 & 11.9 \\
\hline & 2014 & 83 & 11.2 \\
\hline & 2015 & 11 & 1.5 \\
\hline & 2016 & 16 & 2.2 \\
\hline & 2017 & 11 & 1.5 \\
\hline & 2018 & 46 & 6.2 \\
\hline & 2019 & 31 & 4.2 \\
\hline
\end{tabular}

Source: Authors.

The visits were related to the sports activity practiced by the patient at the time of the event (Table 3). The sports activity associated with the highest number of visits was soccer $(87.1 \% ; \mathrm{n}=644)$, followed by cycling $(4.2 \%$; $\mathrm{n}=31)$, swimming $(2.7 \% ; \mathrm{n}=20)$, and jiu jitsu $(1.4 \% ; \mathrm{n}=10)$. 
Table 3. Type of event associated with the care of patients included in the study.

\begin{tabular}{cccc}
\hline Variables & Classification & N & \% \\
\hline Soccer & 644 & 87.1 \\
Cycling & 31 & 4.2 \\
Volleyball & 1 & 0.1 \\
Shuttlecock & 1 & 0.1 \\
Jiu jitsu & 10 & 1.4 \\
Karate & 3 & 0.4 \\
Sports Activity & Boxing & 4 & 0.5 \\
& Judo & 9 & 1.2 \\
& Running & 2 & 0.3 \\
& Krav maga & 3 & 0.4 \\
Swimming & 20 & 2.7 \\
& Skateboard & 8 & 1.1 \\
MMA & 1 & 0.1 \\
& Artistic Gymnastics & 1 & 0.1 \\
Bodybuilding & 1 & 0.1 \\
\hline
\end{tabular}

Source: Authors.

In addition, maxillofacial injuries were categorized according to the type of occurrence (soft parts, simple fracture, multiple fracture, dentoalveolar), location (lower, middle, upper or combined third; right, left, bilateral, central, or combined) and the type of procedure performed on the injury (conservative or surgical) (Table 4).

Table 4. Type of injury, location and procedure adopted for the event for patients included in the study.

\begin{tabular}{cccc}
\hline Variables & Classification & N & \% \\
\hline \multirow{3}{*}{ Injury } & Soft Parts & 247 & 33.4 \\
& Simple Fracture & 228 & 30.9 \\
& Multiple Fracture & 27 & 3.7 \\
& Dentoalveolar & 237 & 32.1 \\
\hline \multirow{3}{*}{ Third of the } & Lower & 161 & 21.8 \\
Face & Middle & 530 & 71.7 \\
& Upper & 28 & 3.8 \\
& Combined & 20 & 2.7 \\
\hline \multirow{3}{*}{ Side of Face } & Right & 80 & 10.8 \\
& Left & 86 & 11.6 \\
& Bilateral & 20 & 2.7 \\
& Central & 543 & 73.5 \\
& Combined & 10 & 1.4 \\
\hline \multirow{2}{*}{ Procedure } & Conservative & 622 & 84.2 \\
& Surgical & 117 & 15.8 \\
\hline
\end{tabular}

Source: Authors.

The largest portion of the consultations performed were related to injury in soft tissues $(33.4 \%, \mathrm{n}=247)$, followed by alveolar tooth and simple fractures, with $32.1 \%$ and $30.9 \%$, respectively. Maxillofacial injuries occurred mainly in the middle 
third of the face $(71.7 \% ; \mathrm{n}=530)$ and on the central side $(73.5 \% ; \mathrm{n}=543)$. In the largest portion of consultations, a conservative procedure was performed $(84.2 \% ; n=622)$.

The variables that showed a statistically significant association with the type of maxillofacial injury that occurred were: gender, age group, period of care in which the injury occurred, sports activity, location of the injury, and type of procedure performed $(\mathrm{p}<0.05)$ (Table 5). Day, month, and year of care did not show a significant association with the type of maxillofacial injury (Table 5).

Table 5. Association between the independent variables and the type of maxillofacial injury investigated in the study patients $(\mathrm{n}=735)$.

\begin{tabular}{|c|c|c|c|c|}
\hline \multirow[b]{2}{*}{ Independent variables } & \multicolumn{3}{|c|}{ Type of Maxillofacial Injury } & \multirow[b]{2}{*}{$\mathbf{p}$} \\
\hline & $\begin{array}{c}\text { Soft Tissue } \\
\text { Injury } \\
\text { N (\%) }\end{array}$ & $\begin{array}{c}\text { Hard Tissue } \\
\text { Injury } \\
\text { N (\%) }\end{array}$ & $\begin{array}{l}\text { Total } \\
\text { n }(\%)\end{array}$ & \\
\hline \multicolumn{5}{|l|}{ Gender } \\
\hline Male & $218(32.3)$ & $457(67.7)$ & $675(100.0)$ & \multirow{2}{*}{$0.045 *$} \\
\hline Female & $27(45.0)$ & $33(55.0)$ & $60(100.0)$ & \\
\hline \multicolumn{5}{|l|}{ Age Range } \\
\hline $\begin{array}{c}\text { Children and Adolescents (0 to } 19 \\
\text { years) }\end{array}$ & $122(37.9)$ & $200(62.1)$ & $322(100.0)$ & \multirow{3}{*}{$0.028 *$} \\
\hline Young Adults (20 to 29 years) & $74(27.5)$ & $195(72.5)$ & $269(100.0)$ & \\
\hline Adults (30 to 59 years) & $49(34.0)$ & $95(66.0)$ & $144(100.0)$ & \\
\hline \multicolumn{5}{|l|}{ Period } \\
\hline Daytime & $76(29.5)$ & $182(70.5)$ & $258(100.0)$ & \multirow{2}{*}{$0.101 *$} \\
\hline Nightly & $169(35.4)$ & $308(64.6)$ & $477(100.0)$ & \\
\hline \multicolumn{5}{|l|}{ Day } \\
\hline Week days & $121(35.4)$ & $221(64.6)$ & $342(100.0)$ & \multirow{2}{*}{0.272} \\
\hline Weekends & $124(31.6)$ & $269(68.4)$ & $393(100.0)$ & \\
\hline \multicolumn{5}{|l|}{ Month } \\
\hline Month off vacation & $177(33.7)$ & $348(66.3)$ & $525(100.0)$ & \multirow{2}{*}{0.729} \\
\hline Month with vacation & $68(32.4)$ & $142(67.6)$ & $210(100.0)$ & \\
\hline \multicolumn{5}{|l|}{ Year } \\
\hline 2008 to 2013 & $180(35.5)$ & $357(66.5)$ & $537(100.0)$ & \multirow{2}{*}{0.860} \\
\hline 2014 to 2019 & $65(32.8)$ & $133(67.2)$ & $198(100.0)$ & \\
\hline \multicolumn{5}{|l|}{ Sports Activity } \\
\hline Soccer & $204(31.9)$ & $436(68.1)$ & $640(100.0)$ & \multirow{2}{*}{$0.029 *$} \\
\hline Others & $41(43.2)$ & $54(56.8)$ & $95(100.0)$ & \\
\hline \multicolumn{5}{|l|}{ Third of the Face } \\
\hline Upper/Lower or Both & $107(51.4)$ & $101(48.6)$ & $208(100.0)$ & \multirow{2}{*}{$<0.001 *$} \\
\hline Medium & $138(26.2)$ & $389(73.8)$ & $527(100.0)$ & \\
\hline \multicolumn{5}{|l|}{ Side of Face } \\
\hline Only one side (Right or Left) & $64(39.0)$ & $100(61.0)$ & $164(100.0)$ & \multirow{3}{*}{ 0.044* } \\
\hline Central region & $167(30.9)$ & $374(69.1)$ & $541(100.0)$ & \\
\hline Bilateral & $14(46.7)$ & $16(53.3)$ & $30(100.0)$ & \\
\hline \multicolumn{5}{|l|}{ Procedure } \\
\hline Conservative & $243(39.2)$ & $377(60.8)$ & $620(100.0)$ & \multirow{2}{*}{$<0.001 * *$} \\
\hline Surgical & $2(1.7)$ & $113(98.3)$ & $115(100.0)$ & \\
\hline
\end{tabular}

$\mathrm{P}=\mathrm{P}$ Value. $* \mathrm{p}<0,05$ in Pearson's chi-square test. $* * \mathrm{p}<0,05$ Fisher's exact test. Source: Authors 


\section{Discussion}

This study demonstrated that the occurrence of maxillofacial injury was more prevalent in adolescents and young adult males as a result of soccer, generally involving soft tissues, midface, and the central region. The treatment performed was mostly conservative, with an association between these variables and injury.

The age group with the highest prevalence was that of individuals aged between 10 and 29 years. Other studies corroborate our findings (Farrington et al., 2012; Imholz et al., 2014; Kyrgidis et al., 2013; Velayutham et al., 2013) and suggest that this is probably because this age group has the largest number of individuals who practice sports more regularly and frequently (Marker et al., 2018; Rodriguez-Ayllon et al., 2019).

The lower number of maxillofacial injuries in children may be related to the greater protection offered by the family, which minimizes the occurrence of injury, especially those associated with sports. However, social habits change with advancing age and the child starts attending school and participating in sports and sports activities, which increases the risk of injury (Zerfowski, Bremerich, 1998).

In adolescence, the increase in the search for physical activities occurs for several reasons: gaining self-confidence, improving personal satisfaction, socializing, maintaining health, and aesthetic factors (Wu et al., 2017). With advancing age, these motivational factors change, but still result in a large number of young adults who practice sports activities in search of improved appearance, fun, and socialization (Omorou et al., 2013). In contrast, the decreased injury observed with advancing age can be explained by the lower number of elderly people who practice sports regularly (Bashkireva et al., 2018).

In addition, a higher prevalence of maxillofacial injury was observed in males, corroborating results found in several studies (Kyrgidis et al., 2013; Velayutham et al., 2013; Abdullah et al., 2013). Despite an increase in the number of women who regularly engage in physical activity, the prevalence of males in this segment is still higher (Marker et al., 2018; Rodriguez-Ayllon et al., 2019), which directly influences the occurrence of injury and justifies the association with males observed in the present study.

In relation to the greater number of visits resulting from maxillofacial injury due to sports activity having been observed at night, it is believed that, in young adults, this prevalence may have been influenced by the greater number of individuals who practice physical activities and perform their activities during this period, after the end of the workday (Mujika et al., 2018).

The distribution of the number of cases per month or year did not reveal any significant association. Contrary to what was evidenced in the present study, Paes et al., 2012, found a higher prevalence of injury during the summer in Brazil, caused by greater exposure to risk situations, such as the practice of outdoor sports activities.

As noted, other authors have assessed the occurrence of maxillofacial injury as a result of sports activities in Chile and Germany and have also identified soccer as the sports activity most related to injury (Elhammali et al., 2010; Barrios et al., 2013). Other studies demonstrate that maxillofacial injury is more related to other sports activities, which suggests a significant influence of the popularity that a given activity has for the local culture (Tozoglu, Tozoglu, 2006; Lieger, Von Arx, 2006; Soares et al., 2018).

For example, Lieger, Von Arx, 2006, assessed the occurrence of maxillofacial injury during sports practice and $24 \%$ of soccer athletes reported having suffered some type of injury. In contrast, the prevalence was $45 \%$ among basketball athletes. In the present study, there was no record of injury associated with basketball.

It was also found that the most prevalent maxillofacial injury was in the soft tissues. Other authors have also demonstrated a high prevalence of injury to soft tissues, mainly affecting the lips and nasal region (Soares et al., 2018; Galic et al., 2018). Regarding the location of the maxillofacial injury, the third of the face most affected was the middle and side of the 
face with the highest occurrence near the center. Other studies have found localization findings similar to ours (Murphy et al., 2015; Elhammali et al., 2010).

The maxillofacial region is one of the areas most prone to injury, due to its prominence and low protection of the region. However, the prevalence of this type of injury may differ when considering the assessed public, age, and sports activities preferably practiced in the region or country (Alharbi et al., 2020). Other publications have shown a different prevalence from those observed in the present study. In some studies, other structures, such as bone and tooth, were more affected (Petrovic et al., 2016; Murphy et al., 2015).

Injuries caused by sports activities can cause considerable physical damage to individuals practicing physical activity and children attending schools (Pauli et al., 2020). However, each injury may require different treatment (Piccininni et al., 2017). In the present study, the majority of patients underwent conservative procedures, such as maxillomandibular block, drug therapy, physical therapy, or dental replantation (Singh et al., 2012).

Contrary to what was observed in this study, Murphy et al., 2015, observed that $70 \%$ of the patients evaluated had undergone surgical procedures. A justification for this discrepancy may lie in the dynamics of the occurrence and treatment of maxillofacial injury.

The complexity of treating maxillofacial injury was demonstrated by a study conducted by Papakosta et al., 2008, in Greece. The authors observed that amateur soccer players who had suffered injury required long treatments, with the majority $(59.0 \%)$ undergoing treatment that lasted for more than 8 years.

The occurrence of this type of injury directly implies personal and social costs, since many cases sometimes require hospitalizations, medications, and surgeries, which generate costs for the government and for the whole society, making its occurrence a concern in terms of public health (Chaves et al., 2017).

Sports Dentistry recommends not only the treatment of maxillofacial injury, but above all it stimulates the prevention and dissemination of information on this theme to minimize its occurrence and, consequently, improve the quality of life of individuals who practice sports activities (Kumamoto et al., 2004).

Limitations were found in the course of this study and they reside in its methodology, of a retrospective and crosssectional character, which does not allow determining causalities and demands greater caution in the interpretation of results, in addition to the data coming only from a reference place for the type of care studied.

\section{Conclusion}

The occurrence of maxillofacial injury was more prevalent in adolescents and young male adults, due to the practice of soccer, typically affecting soft tissues, the middle third of the face, and the central region. The treatment performed on the patients attended was based, mostly, on a conservative procedure.

The approach of several determining factors for the occurrence of maxillofacial trauma and the monitoring of the athlete patient, in the logic of a longitudinal study in different reference institutions, should be considered for future research.

\section{References}

Abdullah, W. A., Al-Mutairi, K., Al-Ali, Y., Al-Soghier, A., \& Al-Shnwani, A. (2013). Patterns and etiology of maxillofacial fractures in Riyadh City, Saudi Arabia. Saudi Dental Journal, 25(1), 33-38.

Alharbi, F. A., Makrami, A. M., Ali, F. M., \& Maghdi, A. A. (2020). Patterns and Etiology of Maxillofacial Fractures: A 5-year Retrospective Study. Journal of Contemporary Dental Pratice, 21(4), 445-452.

Andrade, R. A., Evans, P. L. S., Almeida, A. L. S., Silva, J. D. J. R. D., Guedes, A. M. L., Guedes, F.R., et al. (2010). Prevalence of dental trauma in Pan American games athletes. Dental Traumatology, 26, 248-253. 
Ashley, P., Di Iorio, A., Cole, E., Tanday, A., \& Needleman, I. (2015). Oral health of elite athletes and association with performance: A systematic review. Brazilian Journal of Sports Medicine, 49(1), 14-19.

Barrios, J., Teuber, C., \& Cosmelli, R. (2013). Prevalence of sports-related maxillofacial fractures, at Clinica Alemana Santiago, Chile. International Journal of Oral Maxillofacial Surgery, 42(10), 1220

Bashkireva, A. S., Bogdanova, D. Y., Bilyk, A. Y., Shishko, A. V., Kachan, E. Y., \& Arutyunov, V. A. (2018). Quality of life and physical activity among elderly and old people. Advances in Gerontology, 31(5), 743-750.

Biagi, R., Cardarelli, F., Butti, A. C., \& Salvato, A. (2010). Sports-related dental injuries: Knowledge of first aid and mouthguard use in a sample of Italian children and youngsters. European Journal of Paediatric Dentistry, 11(2), 66-70.

Bruggesser, S., Kühl, S., Solakoglu, Ö., \& Filippi, A. (2020). The prevalence of orofacial injuries in judo: A cross-sectional study. Dental Traumatology, 36(4), 411-416.

Cevada, T., Cerqueira, L. S., Moraes, H. S. D., Santos, T. M. D., Pompeu, F. A. M. S., \& Deslandes, A. C. (2012). Relationship between sport, resilience, quality of life, and anxiety. Archives of Clinical Psychiatry, 39(3), 85-89.

Chaves, S. C. L., Almeida, A. M. F. D. L., \& Rossi, T. R. A., Santana, S. F. D., Barros, S. G. D., Santos, C. M. L. (2017). Oral health policy in Brazil between 2003 and 2014: scenarios, proposals, actions, and outcomes. Ciência \& Saúde Coletiva, 22(6), 1791-1803.

Collins, C., McKenzie, L., Ferketich, A., Andridge, R., Xiang, H., \& Comstock, R. (2016). Dental injuries sustained by high school athletes in the United States, from 2008/2009 through 2013/2014 academic years. Dental Traumatology, 32(2), 121-127.

Correa, M. B., Schuch, H. S., Collares, K., Torriani, D. D., Hallalm, P. C., \& Demarco, F. F. (2010). Survey on the occurrence of dental trauma and preventive strategies among Brazilian professional soccer players. Journal of Applied Oral Science, 18, 572-576.

de Araújo, F. M., Rabello, T. B., Berard, L. T., Coto, N. P., \& Dias, K. R. H. C. (2021). Prevalência de lesões orofaciais eo nível de conhecimento sobre proteção bucal em uma equipe brasileira de judô. Research, Society and Development, 10(6), e57810616133-e57810616133.

Elhammali, N., Bremerich, A., \& Rustemeyer, J. (2010). Demographical and clinical aspects of sports-related maxillofacial and skull base fractures in hospitalized patients. International Journal of Oral Maxillofacacial Surgery, 39(9), 857-862.

Eroje, A.B., Tikare, S., AlQahtani, N. A., Braimoh, O. B., Sundarraj, R. K., Muteq, M. A., et al. (2020). Orofacial trauma awareness among sports teachers in Southern Saudi Arabia. Nigerian Journal of Clinical Pratice, 23(3), 343-348.

Farrington, T., Onambele-Pearson, G., Taylor, R. L., Earl, P., \& Winwood, K. (2012). A review of facial protective equipment use in sport and the impact on injury incidence. Brazilian Journal of Oral Maxillofacial Surgery, 50, 233-238.

Frontera, R., Zanin, L., Ambrosano, G., \& Flório, F. (2011). Orofacial trauma in Brazilian basketball players and level of information concerning trauma and mouthguards, Dental Traumatology, 27, 208-216.

Galic, T., Kuncic, D., Poklepovic, T., Galic, I., Mihanovic, F., Bozic, J., et al. (2018). Knowledge and attitudes about sports-related dental injuries and mouthguard use in young athletes in four different contact sports: water polo, karate, taekwondo and handball. Dental Traumatology, 34(3), 175-181.

Imholz, B., Combescure, C., \& Scolozzi, P. (2014). Is age of the patient an independent predictor influencing the management of cranio-maxillo-facial trauma? A retrospective study of 308 patients. Oral Surgery Oral Medicine Oral Pathology Oral Radiology, 117(6), 690-696.

Kumamoto, D., \& Maeda, Y. (2004). A literature review of sports-related orofacial trauma. General Dentistry, 52(3), 270-280.

Kyrgidis, A., Koloutsos, G., Kommata, A., Lazarides, N., Antoniades, K. (2013). Incidence, aetiology, treatment outcome and complications of maxillofacial fractures. A retrospective study from Northern Greece. Journal of Craniomaxillofacial Surgery, 41(7), 637-643.

Lieger, O., \& Von Arx, T. (2006). Orofacial/cerebral injuries and the use of mouthguards by professional athletes in Switzerland. Dental Traumatology, 22(1), $1-6$

Maillane-Vanegas, S., Codogno, J. S., Turi, B. C., Christofaro, D. G. D., \& Fernandes, R. A. (2018). Prevalence of sports participation among Brazilian adolescents: a systematic review. Brazilian Journal of Kinanthropometry and Human Performance, 20, 388-394.

Marker, A., Steele, R., \& Noser, A. (2018). Physical activity and health-related quality of life in children and adolescents: A systematic review and metaanalysis. Journal of Occupational Health Psychology, 37(10), 893-903.

Martinez, A., Como, J., Vacca, M., Nowak, M., Thomas, C., \& Claridge, J. (2014). Trends in Maxillofacial Trauma: A Comparison of Two Cohorts of Patients at a Single Institution 20 Years Apart. Journal of Oral Maxillofacial Surgery, 72(4), 750-754.

Mujika, I., Halson, S., Burke, L. M., Balagué, G., \& Farrow, D. (2018). An Integrated, Multifactorial Approach to Periodization for Optimal Performance in Individual and Team Sports. International Journal of Sports Physiology and Performance, 13(5), 538-561.

Murphy, C., O’Connell, J. E., Kearns, G., \& Stassen, L. (2015). Sports-Related Maxillofacial Injuries. Journal of Craniofacial Surgery, 26, $2120-2123$.

Nonoyama, T., Shimazaki, Y., Nakagaki, H., \& Tsuge, S. (2016). Descriptive study of dental injury incurred by junior high school and high school students during participation in school sports clubs. International Dental Journal, 66, 356-365.

Omorou, Y. A., Erpelding, M. L., Escalon, H., \& Vuillemin, A. (2013). Contribution of taking part in sport to the association between physical activity and quality of life. Quality of Life Research, 22(8), 2021-2029. 
Paes, J., Paes, F., Valiati, R., Oliveira, M., \& Pagnoncelli, R. (2012). Retrospective study of prevalence of face fractures in southern Brazil. Indian Journal Dental Research, 23(1), 80-86.

Papakosta, V., Koumoura, F., \& Mourouzis, C. (2008). Maxillofacial injuries sustained during soccer: Incidence, severity and risk factors. Dental Traumatology, 24(2), 193-196.

Pauli, L. A., Correa, M. B., Demarco, F. F., \& Goettems, M. L. (2020). The school social environment and oral health-related quality of life in children: a multilevel analysis. European Journal of Oral Science, 128(2), 153-159.

Pereira, A. S., Shitsuka, D. M., Parreira, F. J., \& Shitsuka, R. (2018). Metodologia da pesquisa científica.

Petrović, M., Kühl, S., Slaj, M., Connert, T., \& Filippi, A. (2016). Dental and General Trauma in Team Handball. Swiss Dental Journal, $126,682-686$.

Piccininni, P., Clough, A., Padilla, R., \& Piccininni, G. (2017). Dental and Orofacial Injuries. Clinical Sports Medicine, 36(2), 369-405.

Puciato, D., Borysiuk, Z., \& Rozpara, M. (2017). Quality of life and physical activity in an older working-age population. Clinical Interventions in Aging, 12, $1627-1634$

Ribeiro, A. P. F., Tozzi, T. C. F., Tumelero, S., Carrijo, G. A. N., Vieria, L. R., Loureiro, C., \& de Castilho Jacinto, R. (2021). Knowledge and prevalence of trauma and evaluation of the impact of educational and preventive actions on a population of athletes. Research, Society and Development, 10(4), e16210413913-e16210413913.

Rodriguez-Ayllon, M., Cadenas-Sánchez, C., Estévez-López, F., Muñoz, N. E., Mora-Gonzalez, J., Migueles, J. H., et al. (2019). Role of Physical Activity and Sedentary Behavior in the Mental Health of Preschoolers, Children and Adolescents: A Systematic Review and Meta-Analysis. Sports Medicine, 49(9), $1383-1410$.

Singh, V., Malkunje, L., Mohammad, S., Singh, N., \& Dhasmana, S. (2012). The maxillofacial injuries: A study. National Journal of Maxillofacial Surgery, 3(2), 166-171.

Soares, T. R. C., Magno, M. B., Jural, L. A., Loureiro, J. M., Chianca, T. K., de Andrade Risso, P., et al. (2018). Risk factors for traumatic dental injuries in the Brazilian population: A critical review. Dental Traumatology, 34(6), 445-454.

Tiryaki, M., Ozan, G., Özel, S., Yildirim, Z., Erdemir, U., \& Yucel, T. (2017). Prevalence of dental injuries and awareness regarding mouthguards among basketball players and coaches. The Journal of Sports Medicine and Physical Fitness, 57(11), 1541-1547.

Tozoglu, S., \& Tozoglu, U. (2006). A One-year Review of Craniofacial Injuries in Amateur Soccer Players. Journal of Craniofacial Surgery, $17(5), 825-827$.

Tuna, E. B., \& Ozel, E. (2014). Factors affecting sports-related orofacial injuries and the importance of mouthguards. Sports Medicine, 44(6), 777-783.

Velayutham, L., Sivanandarajasingam, A., O'Meara, C., \& Hyam, D. (2013). Elderly patients with maxillofacial trauma: the effect of an ageing population on a maxillofacial unit's workload. Brazilian Journal of Oral Maxillofacial Surgery, 51(2), 128-132.

Welch, C., Thomson, W., \& Kennedy, R. (2010). ACC claims for sports-related dental trauma from 1999 to 2008 : A retrospective analysis. New Zealand Dental Journal, 106(4), 137-142.

Wu, X. Y., Han, L. H., Zhang, J. H., Luo, S., Hu, J. W., \& Sun, K. (2017). The influence of physical activity, sedentary behavior on health-related quality of life among the general population of children and adolescents: A systematic review. PLoS One, 12(11), e0187668

Young, E. J., Macias, C. R, \& Stephens, L. (2015). Common Dental Injury Management in Athletes. Sports Health, 7(3), 250-255.

Zerfowski, M., \& Bremerich, A. (1998). Facial trauma in children and adolescents. Clinical of Oral Investigation, 2(3), $120-124$. 